Рекомендована д. фрармац. наук, профр. Б. П. Громовиком

УДК 615.12:615.072

DOI 10.11603/2312-0967.2017.4.8345

\title{
ВИЗНАЧЕННЯ ЦІНИ ДОЗИ ДІАГНОСТИЧНОГО ЛІКАРСЬКОГО ЗАСОБУ «ФТОРДЕЗОКСИГЛЮКОЗА 18F, РОЗЧИН ДЛЯ ІН'ЄКЦІЙ»
}

\author{
() В. В. Качанюк
}

\author{
Українська військово-медична академія, Київ \\ Kachanjuk@ukr.net
}

\begin{abstract}
Мета роботи. Визначити ціну дози Фтордезоксиглюкози (ФДГ) для обґрунтування вартості надання медичної послуги з позитронно-емісійної томограсрії (ПЕТ-дослідження).

Матеріали і методи. У роботі використано витратний метод та метод встановлення ціни на основі відчутної цінності товару.

Результати й обговорення. Досліджуючи фрармацевтичний ринок України з виробництва радіофармацевтичних препаратів (РФП), які застосовують для діагностики злоякісних новоутворень за допомогою ПЕТ-дослідження, виникла необхідність у визначенні ціни однієї дози РФП «Фтордезоксиглюкоза 18F, розчин для ін'єкцій» для обґрунтування вартості надання медичної послуги з ПЕТ-дослідження.

Висновки. Запропоновано методику розрахунку ціни однієї дози ФДГ, яка базується на поєднанні витратного методу та методу встановлення ціни на основі відчутної цінності товару. За допомогою витратного методу розраховували собівартість виробництва ФДГ. Визначення вартості медичної послуги з ПЕТ-дослідження доцільно здійснювати з використанням методу встановлення ціни на основі відчутної цінності товару. За допомогою запропонованої методики визначено вартість однієї дози діагностичного лікарського засобу «Фтордезоксиглюкоза 18F, розчин для ін'єкцій».
\end{abstract}

Ключові слова: Фтордезоксиглюкоза 18F; діагностичний лікарський засіб; доза; ціна; змінні витрати; постійні витрати.

Вступ. Розвиток як світового, так і українського фрармацевтичного ринку з виробництва радіофармацевтичних препаратів (РФП) має власну специоріку, тому що споживачами діагностичних РФП є лікарірентгенологи, які здійснюють позитронно-емісійну томографрію (ПЕТ) з використанням РФП [1-3]. Унікальність фрармацевтичного ринку з виробництва РФП полягає у прагненні держави задовольнити населення України в наданні своєчасної якісної медичної допомоги у діагностиці онкологічних захворювань та збереженні здоров'я нації [4]. Розвиток прогресивного напрямку ядерної медицини у ранній діагностиці онкологічних захворювань і визначають формування попиту РФП, від якого, у свою чергу, залежать пропозиції на ці препарати, їх асортимент та обсяги виробництва.

Проблематику створення нових ПЕТ-центрів, розрахунок вартості монтажу виробничих приміщень, обладнання та вартості однієї дози ФДГ вивчали закордонні вчені О. С. Федорова, В. В Орловська, В. І. Малєєв, Р. Ш. Ліу, Т. А. Скворцова, Ю. М. Бєлоконь, Т. Ф. Савєльєва, Ч. В. Чанг, Ч. Л. Чен, Р. М. Красікова [5].

Оптимізація системи онкологічної допомоги в Україні висвітлена у низці наукових досліджень. Серед них слід відзначити роботи, в яких проведено комплексну оцінку стану її організації та діяльності закладів охорони здоров'я ресурсного та матеріально-технічного забезпечення, визначення сучасної стратегії розвитку [6, 7].

Медико-соціальне обґрунтування організації ПЕТцентрів із застосуванням РФП в Україні досліджували вчені: І. П. Семенів, Я. В. Кметюк, А. С. Котуза, О. І. Солодянникова $[2,3,6]$, однак питання економічної доступності медичної послуги 3 ПЕТдослідження $з$ застосуванням ФДГ для всіх верств населення України вивчені недостатньо і потребують подальшого дослідження. Так, публікації вітчизняних дослідників - І. Б. Дутчак, Б. П. Громовик, О. І. Андрусь - висвітлюють ціну як одну зі складових елементів комплексу фрармацевтичного маркетингу [810]. Застосування методів змінних і постійних витрат для розрахунку ціни на лікарський засіб описано в працях А. Ф. Павленка, А. В. Войчака, С. М. Ілляшенка, Я. В. Литвиненка, Ю. Г. Тормоса, М. А. Окландера, О. П. Чукурної.

У процесі наукового пошуку теоретичних та правових засад державного регулювання цін на фрармацевтичному ринку, які застосовують методи аналізу порівняння та аналогії щодо формування цін на лікарські засоби у різних часових періодах, виявлено, що ціна виконує важливі фрункції та визначає основні завдання: отримання доходу від реалізації лікарсько-

ISSN 2312-0967. Pharmaceutical review. 2017. № 4 
го засобу, інформування виробника про обсяги попиту на лікарський засіб, а споживача лікарського засобу - про можливості задоволення його потреби. Від ціни залежать досягнуті комерційні задачі, а доцільно обрана цінова стратегія впливає на підвищення конкурентоспроможності та ефрективності фрармацевтичної діяльності.

Фармацевтичний ринок РФП вважається таким, що суттєво впливає на національну безпеку країни, оскільки ступінь задоволеності та доступності споживачів РФП значною мірою впливає на тривалість і якість життя пацієнтів 3 онкологічними захворюваннями. Визначення ціни дози ФДГ сприяє підпорядкуванню виробництва РФП суспільним потребам, а обґрунтований рівень цін - економічному зростанню, а також забезпечує конкурентне середовище, орієнтує виробництво РФП на інноваційний зміст, скорочує витрати виробництва та підвищує якість надання медичної послуги.

Таким чином, визначення ціни однієї дози ФДГ дозволяє обґрунтувати вартість надання медичної послуги з ПЕТ-дослідження та узгодити виробництво діагностичних лікарських засобів із суспільними потребами. Запропонований механізм визначення ціни однієї дози ФДГ у перспективі буде застосовуватися при створенні нових виробничих підрозділів ПЕТцентрів України.

В умовах сучасного нестабільного розвитку ринкових відносин в економіці України проблема підвищення ефективності вітчизняного виробництва РФП набуває нових особливостей і залишається актуальною. Одним із шляхів їі розв'язання $€$ визначення ціни однієї дози ФДГ, яка, з одного боку, забезпечить закладу охорони здоров'я компенсацію витрат на отримання цільового прибутку, а, з іншого, відповідає ринковим позиціям продукції (серед конкурентів) та задовольняє запити споживачів. Ціна як елемент комплексу маркетингу забезпечує прибуток закладу охорони здоров'я і $є$ одним із гнучких елементів цього комплексу, адже вона $€$ величиною динамічною та потребує постійного аналізу.

Матеріали і методи. Об'єктом дослідження була ФДГ, яка широко застосовується у ядерній медицині для проведення ПЕТ-діагностики. Співпрацюючи 3 ПЕТ-центрами України, а саме Всеукраїнським центром радіохірургії у складі Клінічної лікарні «Феофанія» та Центром ядерної медицини Київського онкологічного центру, обґрунтовано актуальність розрахунку ціни однієї дози ФДГ. Їх досвід показав, що на сьогодні доцільно використовувати поєднання витратного методу та методу встановлення ціни на основі відчутної цінності товару, що зумовлено особливостями ПЕТ-досліджень та діагностичних лікарських засобів, а також специфічними підходами до роботи ПЕТ-центрів на ринку. При цьому комплекс проведених досліджень визначив, що оптимальним методом є витратний метод [9-12].
Результати й обговорення. Вартість медичної послуги з ПЕТ-дослідження включає ціну дози ФДГ та ціни комплексу послуг із діагностики онкологічних захворювань та контролю динаміки лікування. Ціна дози ФДГ міститься в розрахунку витрат закладу охорони здоров'я на виробництво ФДГ. При цьому потрібно розраховувати собівартість продукції та очікуваний прибуток, за допомогою яких визначається кінцева відпускна ціна ФДГ.

На підставі проведених досліджень літературних джерел та аналізу досвіду світових закладів охорони здоров'я, які надають послуги з ПЕТ-дослідження, визначено, що до змінних витрат доцільно відносити прямі витрати на виробництво та реалізацію ФДГ, а саме витрати на сировину, матеріали та електренергію, заробітну плату основного технологічного персоналу з відрахуваннями.

До постійних витрат віднесли амортизаційні відрахування технологічного обладнання, вартість валідаційних досліджень та витрати, пов'язані з організацією виробничого процесу (валідаційний статус).

Витрати на валідаційний статус включає постійні витрати на проведення валідаційних досліджень виробничих приміщень та обладнання (які проводяться по аутсорсингу двічі на рік), витрати на заміну фрільтрів у системі повітропідготовки.

Розрахунок амортизації основного обладнання для виробництва ФДГ доцільно проводити прямолінійним методом, який передбачає, що річна сума амортизації (Ar) визначалася діленням вартості, яка амортизується, (Va) на строк корисного використання обладнання основних засобів (N). Для основного обладнання, яке використовується для виробництва ФДГ, було встановлено строк використання 20 років 3 нульовою ліквідаційною вартістю.

Розрахунок величини змінних і постійних витрат наведено в таблиці 1.

Ціну ФДГ розраховували з огляду на собівартість виробництва одиниці продукції та запланованого прибутку (на підставі проведених досліджень визначено, що доцільний рівень рентабельності з урахуванням нижнього порогу ціни приймати в розмірі $20 \%)$ :

$Ц_{\text {одніеї серії фдг }}=43333.33+8666.66=51999.996$ грн.

Серія ФДГ застосовується для надання медичної послуги з ПЕТ-діагностики 7 пацієнтам, тому:

$Ц_{\text {однієі дози фдг }}=51999.996 / 7=7428.57$ грн.

Беручи до уваги, що споживачами ФДГ є лікарірентгенологи, які надають медичну послугу в діагностиці онкологічних захворювань за допомогою ПЕТдосліджень, ціна однієї дози ФДГ входить у вартість медичної послуги закладу охорони здоров'я, який спеціалізується на наданні діагностичних послуг. Тому доречним є визначення вартості медичної послуги з ПЕТдослідження із застосуванням методу встановлення ціни на основі відчутної цінності лікарського засобу, що зумовлено специфікою використання ФДГ [5]. Розра-

ISSN 2312-0967. Фармацевтичний часопис. 2017. № 4 
Таблиця 1. Результати розрахунку величини собівартості виробництва «Фтордезоксиглюкоза 18F, розчин для ін'єкцій»

\begin{tabular}{|c|c|c|}
\hline $\begin{array}{l}\text { № } \\
\text { 3/ח }\end{array}$ & $\begin{array}{c}\text { Статті витрат на виробництво } \\
\text { «Фтордезоксиглюкоза 18F, розчин для ін'єкцій» }\end{array}$ & $\begin{array}{l}\text { Витрати на одну } \\
\text { серію, грн }\end{array}$ \\
\hline \multicolumn{3}{|c|}{ Змінні витрати } \\
\hline 1 & $\begin{array}{l}\text { сировина: } \\
\text { трифрлат манози } \\
\text { набір реагентів } \\
\text { вода, збагачена ізотопом }{ }^{18} \mathrm{O}\end{array}$ & 7294.05 \\
\hline 2 & $\begin{array}{l}\text { матеріали } \\
\text { набір змінних частин } \\
\text { набір очисних колонок } \\
\text { набір підготовчих колонок } \\
\text { флакони скляні } \\
\text { стерильні } 10 \text { мл } \\
\text { набір для розливу }\end{array}$ & 1919.00 \\
\hline 3 & $\begin{array}{l}\text { заробітна плата основного персоналу (інженер-радіофізик, інженер-радіохімік, } \\
\text { радіофрармацевт-провізор, дозиметрист, уповноважена особа, прибиральник } \\
\text { виробничих приміщень) з відрахуваннями }\end{array}$ & 3005.98 \\
\hline 4 & контроль якості & 10182.23 \\
\hline 5 & засоби індивідуального захисту (рукавички, маски, шапочки) & 22.20 \\
\hline 6 & енергоносії & 32.02 \\
\hline 7 & срільтр G4 & 31.67 \\
\hline 8 & фрільтр F9 & 14.58 \\
\hline 9 & НЕРА-фрільтр & 390.63 \\
\hline \multicolumn{3}{|c|}{ Постійні витрати: } \\
\hline 8 & амортизаційні відрахування основного обладнання & 19667.49 \\
\hline 9 & валідаційні дослідження виробничих приміщень і обладнання & 773.48 \\
\hline \multicolumn{2}{|r|}{ Повна собівартість } & 43333.33 \\
\hline
\end{tabular}

хунки здійснювали для певної категорії споживачів, які погоджуються оплачувати не лише ціну дози ФДГ, а й комплекс медичних послуг, а саме введення лікарського засобу в організм пацієнта, сканування частини чи всього тіла (залежно від медичних показань), оцінювання результатів та встановлення діагнозу.

Таким чином, вартість однієї дози діагностичного лікарського засобу «Фтордезоксиглюкоза 18F, розчин для ін'єкцій», визначена за допомогою запропонованих методів, складає 7428,57 грн.

Висновки. Проведено аналіз останніх досліджень та публікацій, який виявив спрацьованість досліджуваної проблематики. Виявлено необхідність визначення ціни однієї дози ФДГ, що дозволить обґрунтувати вартість надання медичної послуги 3 ПЕТдослідження та узгодити виробництво діагностичних лікарських засобів із суспільними потребами. Запропоновано методику розрахунку ціни однієї дози ФДГ, яка базується на поєднанні витратного методу та методу встановлення ціни на основі відчутної цінності товару. За допомогою витратного методу розраховували собівартість виробництва ФДГ. Визначення вар- тості медичної послуги з ПЕТ-дослідження доцільно здійснювати з використанням методу встановлення ціни на основі відчутної цінності товару. За допомогою запропонованої методики визначено вартість однієї дози діагностичного лікарського засобу «Фтордезоксиглюкоза 18F, розчин для ін'єкцій».

Отже, запропоновані підходи визначення ціни однієї дози ФДГ дозволяють обґрунтувати вартість медичної послуги з ПЕТ-дослідження та проаналізувати доступність цієї медичної послуги для онкологічних хворих.

Основою визначення ціни дози ФДГ у ПЕТ-центрі $€$ обґрунтування вартості медичної послуги, яка складається з вартості виробництва ФДГ та безпосередньо вартості медичної послуги. Ціна однієї дози ФДГ має свою специфіку, що залежить від наявності кваліфікованого медичного персоналу та матеріальнотехнічного забезпечення томографрами для сканування у закладі охорони здоров'я, тобто технічних можливостей обслуговування пацієнтів. 3 іншого боку, ця послуга повинна бути доступною для пацієнтів. Це і зумовлює необхідність подальших розробок стосовно оптимізації вартості однієї дози ФДГ.

ISSN 2312-0967. Pharmaceutical review. 2017. № 4 
Фармакоекономіка

Pharmacoeconomics

\title{
ОПРЕДЕЛЕНИЕ ЦЕНЫ ДОЗЫ ДИАГНОСТИЧЕСКОГО ЛЕКАРСТВЕННОГО СРЕДСТВА «ФТОРДЕЗОКСИГЛЮКОЗА 18F, РАСТВОР ДЛЯ ИНЪЕКЦИЙ»
}

\section{В. В. Качанюк}

\section{Украинская военно-медицинская академия, Киев}

Kachanjuk@ukr.net

\begin{abstract}
Цель работы. Определить цену дозы Фтордезоксиглюкозы (ФДГ) для обоснования стоимости оказания медицинской услуги по позитронно-эмиссионной томографии (ПЭТ-исследованию).

Материалы и методы. В работе использованы затратный метод и метод установления цены на основе ощущаемой ценности товара.

Результаты и обсуждение. Исследуя фрармацевтический рынок Украины по производству радиосрармацевтических препаратов (РФП), которые применяются для диагностики злокачественных новообразований с помощью ПЭТисследования, возникла необходимость в определении цены одной дозы РФП «Фтордезоксиглюкоза 18F, раствор для инъекций» для обоснования стоимости оказания медицинской услуги по ПЭТ-исследование.

Выводы. Предложена методика расчета цены одной дозы ФДГ, основанная на сочетании затратного метода и метода определения цены на основе ощущаемой ценности товара. С помощью затратного метода рассчитывалась себестоимость производства ФДГ. Стоимость медицинской услуги по пЭТ-исследованию целесообразно рассчитывать, используя метод установления цены на основании ощущаемой ценности товара. С помощью предложенной методики определена цена одной дозы диагностического лекарственного средства «Фтордезоксиглюкоза 18F, раствор для инъекций».
\end{abstract}

Ключевые слова: Фтордезоксиглюкоза 18F; диагностическое лекарственное средство; доза; цена; переменные затраты; постоянные затраты.

\section{PRICING A DOSE OF THE DIAGNOSTIC MEDICINAL PRODUCT FLUDEOXYGLUCOSE 18F SOLUTION FOR INJECTIONS}

\section{V. Kachaniuk}

Ukrainian Military Medical Academy, Kyiv

Kachanjuk@ukr.net

The aim of the work. Calculating the price of a dose of Fludeoxyglucose (FDG) to justify the cost of providing a positron emission tomography (PET).

Materials and Methods. The cost method and the method of establishing prices based on the tangible value of the goods were used in this study.

Results and Discussion. While studying the pharmaceutical market of Ukraine for the production of radiopharmaceuticals used for diagnostics of malignant neoplasms with PET, it became necessary to estimate the price per one dose of the radiopharmaceutical «Fludeoxyglucose $18 \mathrm{~F}$ solution for injections» to justify the cost of providing PET research services. Conclusions. The proposed method for calculating the price of a single FDG dose is based on a combination of the cost method and the method of establishing the price based on the tangible value of the product. The cost of FDG production was calculated with the cost method. The cost of medical services for PET research should be calculated using the method of establishing prices based on the tangible value of the goods. The price of one dose of the diagnostic drug «Fludeoxyglucose $18 \mathrm{~F}$ solution for injections» is determined by using the proposed technique.

Key words: Fludeoxyglucose 18F; diagnostic drug; dose; price; variable costs; fixed costs.

\section{Список літератури}

1. Досвід впровадження та перші підсумки застосування позитронно-емісійної томографрії у Всеукраїнському центрі радіохірургії / І. П. Семенів, Я. В. Кметюк, О. І. Москалець [та ін] // Променева діагностика. Променева терапія. - 2013. - № 2-3. - С. 88-92.

2. Роль 18-ФДГ ПЕТ/КТ у плануванні радіотерапії пухлин аноректальної локалізації: стан проблеми /
О. О. Колеснік, А. В. Ашихмін, О. І. Солодянникова [та ін.] // Клінічна онкологія. - 2015. - № 4 (20). - С. 15-21. 3. ЗастосуванняпоєднаногоПЕТ-КТ-дослідження в діагностиці онкологічних захворювань / О. М. Клюсов, М. М. Фірсова, Д. С. Осинський [та ін.] // Онкология. - 2012. - № 1. - С. 55-58. 4. Законодавство України. Розпорядження: Про схвалення Концепції Загальнодержавної програми

ISSN 2312-0967. Фармацевтичний часопис. 2017. № 4 
боротьби з онкологічними захворюваннями на 2007 2016 р. [Електронний ресурс] / Кабінет Міністрів України - 10 липня 2006. - № 393-p. - Режим доступу: http:// www.moz.gov.ua/ua/portal/Pro_20060505_0.html.

5. Разработка подходов к асимметрическому синтезу меченного фртором-18 аналога L-трео-3,4дигидроксифенилсерина (6-L-трео-[18F]FDOPS) нового радиотрейсера для визуализации транспортеров норэпинесрина методом позитронной эмиссионной томограсри / О.С. Федорова [та ін] ; Известия Академии Наук. Серия химическая. - М., 2014. - 1167 с. - Деп. Известия Академии Наук. Серия химическая 2014, № 5. 6. Організація роботи центру ПЕТ/КТ у закладі охорони здоров'я: методичні рекомендації / [Семенів І. П., Кметюк Я. В., Котуза А. С., Миротюк Г. В.]. - К., 2014. - 106 с. 7. Стан надання онкологічної допомоги населенню України / 3. П. Сидоренко, В. Г. Дубініна, В. І. Хоменко [та ін.] ; за ред. В. В. Шафранського. - К., 2016. - С. $381-388$.

8. Планування рентабельності виробництва [Електронний ресурс] / М. В. Бець // Економіка України. -
2000. - № 2. - С. 87. - Режим доступу : www.mikroekonomika/chinniki_zrostannja_efektivnosti_virobnictva_dijalnosti_pidpriemstva_referat/40-1-0-3916.

9. Методика проведення аналізу беззбитковості [Електронний ресурс] / В. Усенко // Аптека - 2002. № 2 323). - Режим доступу: http://www.apteka.ua/article/12557.

10. Менеджмент і маркетинг у фрармації / [Громовик Б. П., Гасюк Г. Д., Левицька О. Р. та ін.] ; за ред. О. Є. Кузьміна і Б. П. Бровика. - В. : Нова книга, 2008. - 448 с.

11. Андрусь О. І. Аналіз проблем сучасного ціноутворення в Україні та обґрунтування шляхів підвищення його есрективності / О. І. Андрусь // Ефективна Економіка. 2013. - № 5. - С. 89-91.

12. Ціноутворення медичної допомоги в умовах ринкової економіки. Економіко-математична модель для визначення вартості скринінгових обстежень [Електронний ресурс]. - Режим доступу: http:// www.medcollege.te.ua/sayt1/Practics/Praktiks_ marceting/5cinoutvjrennia.htm.

\section{References}

1. Semeniv IP, Kmetyuk YV, Moskalets OI, Ashykhmin AV. [Experience of introduction and first results of positron emission tomography in the All-Ukrainian Center of Radiosurgery]. Promeneva diahnostyka. Promeneva terapiia. 2013;2(3): 88-92. Ukrainian.

2. Kolesnik OO, Ashykhmin AV, Solodiannikova OI, Kmetyuk YV, Musaeva KO. [The role of 18-FDG PET in the planning of radiotherapy of anorectal localization tumors: the state of the problem]. Klinichna oncolohiia. 2015;4(20): 15-21. Ukrainian.

3. Kliusov OM, Firsova MM, Osinskyi DS, Oleinychenko OH, Kholodna AV, Lola OI. [Application of a combined PET-CT study in the diagnosis of oncological diseases] Onkolohiia. 2012; 14(1): 55-58. Ukrainian.

4. On Approval of the Concept of the National Program for combating cancer diseases for 2007-2016. [Internet]. Kiev: Cabinet of Ministers of Ukraine; 2006 [cited 2017 Octob. 23]. Available from: Available from: http://www.moz.gov.ua/ ua/portal/Pro_20060505_0.html. Ukrainian.

5. Fedorova OS, Orlovska VV, Maleev VI, Belokon YN, Saveleva TF, Chang CV, et al. Development of approaches to the asymmetric synthesis of the fluorine-18 analogue of L-threo-3,4-dihydroxyphenylserine (6-L-threo- [18F] FDOPS), a new radiotracker for the visualization of norepinephrine transporters by positron emission tomograph. 2014; (5):1169-77. Russian.

6. Semeniv IP, Kmetyuk YV, Kotuza AS, Myrotyuk HV. Organization of work of the center PET in public health establish-

ment: guidelines [Організація роботи центру ПЕТ/КТ у закладі охорони здоров'я: методичні рекомендації]. Kyiv; 2014. Ukrainian.

7. Sydorenko SP, Dubinina VH, Khomenko VI, Dsyuba OM, Kmetyuk YV. The state of providing cancer care to the population of Ukraine. Kyiv: Ministry of Health of Ukraine. State Enterprise «Ukrainian Institute for Strategic Studies of Ministry of Health of Ukraine»; 2012. 453p. Report № 7. Ukrainian.

8. Bets MV. Planning profitability of production. Ekonomika Ukrainy [Electronic source]. [cited 2017 Octob. 23]. Available from: www.mikroekonomika/chinniki_zrostannja_efektivnosti_virobnictva_dijalnosti_pidpriemstva_referat/40-1-0-3916. Ukrainian.

9. Usenko $\mathrm{V}$. The method of conducting an analysis of break-even. Apteka, 2:323 [Electronic source]. Available from: http://www.apteka.ua/article/12557. Ukrainian.

10. Hromovyk BP, editors. Management and marketing in pharmacy. [Менеджмент і маркетинг у фрармації ] Vinnytsia: Nova knyha; 2008. Ukrainian.

11. Andrus OI. [Analysis of problems of modern pricing in Ukraine and substantiation of ways to increase its efficiency]. Efektyvna ekonomika. 2013;(5): 89-91. Ukrainian.

12. Pricing of health care in a market economy. An economic and mathematical model for determining the cost of screening surveys [Electronic source]. [cited 2017 Octob. 23]; 2(323). Available from: http://www.medcollege.te.ua/ sayt1/Practics/Praktiks_marceting/5cinoutvjrennia.htm. Ukrainian.

Отримано 30.08.2017 